\title{
Bicultural Architecture
}

Christine McCarthy, School of Architecture, Victoria University

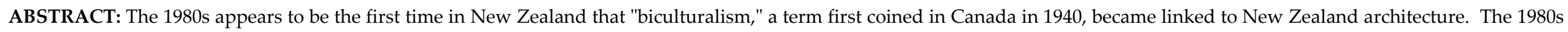

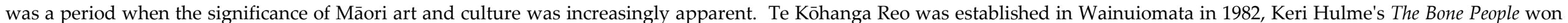

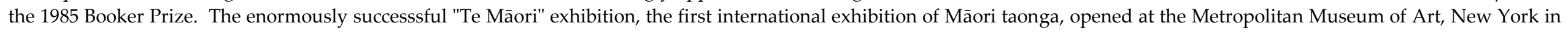
1984, later touring New Zealand in 1986 renamed: "Te Māori: Te Hokinga mai. The Return home."

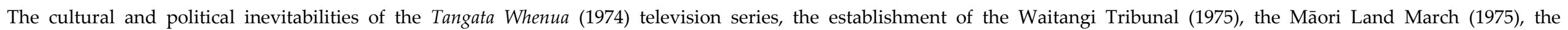

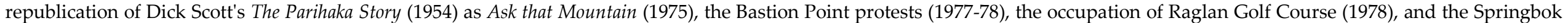
Tour (1981), meant that by the 1980s Pākehā and Māori were questioning their relative postions in New Zealand society.

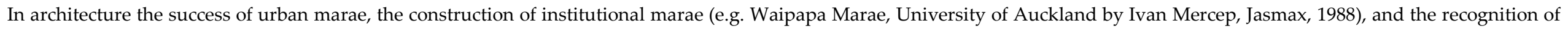

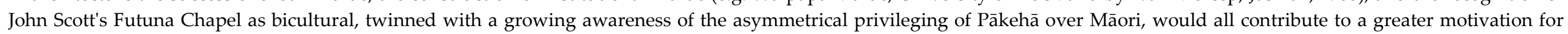

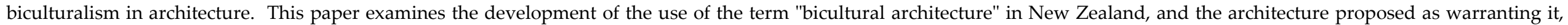
during this period of New Zealand's history.

In 1986 Ranginui Walker quoted Chief Seattle addressing the US government in the nineteenth century in order to illustrate the contrary perspectives of indigenous and metropolitan societies; of Māori and Pākehā:

"How can you buy or sell the sky, the warmth of the land? The idea is strange to us. If we do not own the freshness of the air and the sparkle of the water how can we buy them?"1

At the time of Walker's quotation, mainstream New Zealand was on the edge of embracing, or at least using, the word "bicultural" to describe and discuss relationships between

\footnotetext{
${ }^{1}$ Walker The Meaning of Biculturalism $\mathrm{p} 1$.
}

Māori and Pākehā. The word appears to have originated in Canada, and date from $1940 .{ }^{2}$ It seems to have been first used in New Zealand from at least the 1950s, ${ }^{3}$ but it wasn't until the 1980s that the term gained wider currency. The cultural and political inevitabilities of the Tangata Whenua (1974) television series, the establishment of the Waitangi Tribunal (1975),

2 The Oxford English Dictionary refers to Caroline F. Ware's (ed). Cultural Approach to History (New York: Columbia University Press, 1940) II: 67, as the first known useage of "bi-cultural." "Bicultural" p 173. In contrast, Rodgers locates the first useage of bi-cultural in the 1920s but does not state whether this is a New Zealand useage. Rodgers "House of Biculturalism" p 4. ${ }^{3}$ Sinclair "Tolaga Bay and its District High School" p 54. the Māori Land March, led by Whina Cooper (1975), the republication of Dick Scott's The Parihaka Story (1954) as Ask that Mountain (1975), the Bastion Point protests (1977-78), the occupation of Raglan Golf Course (1978), and the national divisions caused during the Springbok Tour (1981), meant that by the beginning of the 1980s even mainstream Pākehā and Māori were questioning their relative positions in New Zealand society. As Deidre Brown has noted, the anticipation of the sesqui-centennial in 1990, also spurred on cultural investigations, ${ }^{4}$ echoing a similar

\footnotetext{
4 "These interactions became more important in the work
} of institutional building designers as a consequence of a 
interest in the runup to the 1940 New Zealand Centennial, when Māori culture was highlighted because it was a point where New Zealand was identifiably distinct from the rest of the world.

The 1980s was also a decade when the significance of Māori art and culture became increasingly apparent to all New Zealanders. Te Kōhanga Reo was established in Wainuiomata in 1982, Keri Hulme's The Bone People won the 1985 Booker Prize. The enormously successsful "Te Maori" exhibition (the first international exhibition of Māori taonga), opened at the Metropolitan Museum of Art, New York in 1984, later touring New Zealand in 1986 renamed: "Te Maori: Te Hokinga mai. The Return home." That same year James Belich wrote The New Zealand Wars (1986) which "demonstrated how the British consistently underestimated the strength and resourcefulness of the Maori," 5 and Claudia Orange's landmark The Treaty of Waitangi

greater awareness, in the general community and government, of the Treaty of Waitangi, around the sesquicentennial anniversary of its signing in 1990." Brown Māori Architecture p 146.

${ }^{5}$ Mulgan "Can the Treaty of Waitangi provide a

Constitutional Basis for New Zealand's Political Future?" p 53.
(1987) was published the year following. Both of these books, like Scott's Ask that Mountain, pointed to disparities between past and current (and Māori and Pākehā) versions of historical events.

\section{Before the 1980s}

Prior to the 1980s the most comprehensive statement on biculturalism internationally was possibly the Canadian Report of the Royal Commission on Bilingualism and Biculturalism (1967) which examined English: French biculturalism. Its terms of reference were to "inquire into and report upon the existing state of bilingualism and biculturalism in Canada and to recommend what steps should be taken to develop the Canadian Confederation on the basis of an equal partnership between the two founding races." Writing, following his membership of the Commission, Hugh Innis defined biculturalism within the idea of culture as "a way of being, thinking, and feeling," and covering:

the state of each of the two cultures, and the opportunity of each to exist and flourish ... [and] the coexistence and collaboration of these two cultures within our country; that is to say, the set of conditions which will enable

${ }^{6}$ Innis Bilingualism and biculturalism [foreword] n.p. members of these two culture to co-operate effectively. ${ }^{7}$

The few references to biculturalism in New Zealand publications prior to the 1980s rarely refer to architecture. Biculturalism is closely related to bilingualism, and at times it is interchanged with "integration" - though integration is qualified as requiring "the preservation of the identities of both cultures." 8 The bicultural is given positive associations, and is primarily used by politicans, government officials or members of the church.

Five instances, for example, occur in $\mathrm{Te} A o$ Hou: The New World, beginning in July 1958, when bi-culturalism was seen as an important quality for teachers of Māori students. D Sinclair (Member, Hawkes Bay Education Board) wrote that "the Dominon and the Education Department and the various Education Boards must face up to the insistent demand for bi-cultural teachers in all schools with a significant number of Maoris on their rolls." 9 A year later the point is reinforced again by Sinclair, noting the limiting factor for Māori language and culture to be taught in

\footnotetext{
${ }^{7}$ Innis Bilingualism and biculturalism $\mathrm{p} 4$

8 "Dedication of Carving" p 40.

${ }^{9}$ Sinclair paraphrased, "[untitled]" p 44.
} 
primary schools (in this case Tolaga Bay School), was the availability of bilingual teachers, referred to later as "such bicultural teachers." 10

A decade later, "bicultural" was the adjective used to describe a matapihi (or carved window frame) carved by Waka Graham, given as a gift to the Bible Society from the Māori Section of the National Council of Churches. The carving:

had special significance ... of the true nature and meaning of integration - it was made from native timbers, but with Western tools; was in an ancient form, but placed in a modern 20th century building and was a beautiful example of traditional Maori art, but included modern glass and fittings. ${ }^{11}$

The kōrupe (or lintel) included a fish which emerged from the carving as a "Maori fish with the Pakeha tail ... [symbolising] the true mingling of Maori and Pakeha in the work of the Maori Bible," and the poutaha (or sideposts) "show how the Maori evolved from a one-tongued man into a bi-lingual, bicultural man through the coming of the Pakeha man with a mission from God."12 Biculturalism

${ }^{10}$ Sinclair "Tolaga Bay and its District High School" p 54.

11 "Dedication of Carving" p 40.

12 "Dedication of Carving" p 41. here translates from bilingualism represented by a cloven-tongued figure.

The opening speech of Taumarunui Mental and Social Health week in 1971, by Stanley WP Mirams (Director of the Mental Health Division 1969-78) was "on bi-cultural relations."13 Mirams (1918-87) was the first Director of Mental Health in New Zealand, and was awarded an OBE in 1980. There is no indication in the report of how Mirams defined or contextualised his notion of bicultural relations. Another speech, reported in $\mathrm{Te}$ Ao Hou two years later, this time by Matiu Rata (Minister of Maori Affairs) at the Maori Welfare Officers' Association conference (at Parewahawaha Marae, Bulls), stated that "the responsibility to build a successful bi-cultural society based on the abundance of goodwill present throughout the community rested on everyone ... New Zealand [he said] would benefit greatly from some aspects of Maori life."14

Biculturalism, from its early useage in New Zealand, is able to describe action, object, people and relationships, and appears to

13 "Mental and Social Health Week" p 13.

14 "Maori Welfare Officers Meet the Minister" p 14. primarily reflect Māori adaptation to, or negotiation with Pākehā colonisation (language, religion, iconography).

\section{Defining Biculturalism in the 1980s}

The discussion of what biculturalism is or might be appears to have first been formally recorded in the later half of the 1980s, the period of time when Paul Reeves, the first Māori Governor General, was in office. ${ }^{15}$ Ranginui Walker's The Meaning of Biculturalism (1986), Raj Vasil's Biculturalism: Reconciling Aotearoa with New Zealand (1988), as well as speculations, such as Richard Mulgan's "Can the Treaty of Waitangi provide a Constitutional Basis for New Zealand's Political Future?" (1989), are examples. Government Departments also initiated "Bicultural Policy" including: the Ministry of Foreign Affairs and Trade (1976), the National Library (1987), the Ministry of Health (1987), and the Department of Scientific and Industrial Research (1989). The Anglican Church produced a report Ripoata a te Komihana mo te Kaupapa Tikanga Rua: The Report of the Bi-cultural Commission of the

${ }^{15}$ Paul Reeves is affiliated to Te Āti Awa and was Governor General from 1985-90, the period of the 1980s when reference to biculturalism entered mainstream New Zealand. 
Anglican Church on the Treaty of Waitangi (1986).

Walker's essay located biculturalism in terms of the two cultures of the "indigenous people and the culture of metropolitan society," contrasting the mythology, spiritual beliefs, divine origin and relationships between the people, the earth and its resources of indigenous people with the commodification (of land, its resources and people) and alienation (from the land, its resources and people) of capitalism. ${ }^{16}$ In this respect it contrasts the Canadian French/English precedent. He located the signing of the Treaty of Waitangi as illustrating the contrast between Māori's bicultural understanding of Māori-Pākehā relationships, and Hobson's monocultural perspective, embodied in his declaration "He iwi tahi tātou" - We are one people:

This is the charter for the one people myth in New Zealand which denies the otherness of Maori people as expressed in their language, culture and customary useages. It is the charter for the policy of assimilation which successive governments since the time of Sir George Grey applied to the Maori people. In 1960 this policy was disguised and dressed up by the new word

${ }^{16}$ Walker The Meaning of Biculturalism pp [1], 2. of integration in the Hunn Report. ${ }^{17}$

In contrast to Pākehā, Walker located urban Māori (in particular) as "bicultural New Zealanders":

There is a cultural revolution afoot in New Zealand whereby urban Maori are redefining a bicultural future for New Zealand ... biculturalism means more than Pakehas learning a few phrases of Maori language and how to behave on the marae. It means they will have to share what they have monopolised for so long, power, privilege and occupational security. ${ }^{18}$

Walker's identification of the fundamental contradiction of indigenity and capitalism, the validity of cultural difference, and powersharing as critical to meaningful biculturalism made explicit a robust test for biculturalism, distinct from assimilation and integration. While assimilation advocated the gradual extinction of Māori through "absorption" into Western society, biculturalism, defined by Walker drew on the notions of equity rather than equalness. Assimilation was a kind of cultural consumption architecturalised by the exhibition display of Ngāti Awa's wharenui Hotunui half-eaten by the Pākehā architecture of the Auckland War Memorial Museum.

${ }^{17}$ Walker The Meaning of Biculturalism $\mathrm{p} 3$.

${ }^{18}$ Walker The Meaning of Biculturalism $\mathrm{p} 5$.
Mike Linzey has more generously described this as "binary [and bicultural] architecture," as follows:

the Auckland War Memorial Museum, built in the 1920s, which metaphorically "ingested" an ancestral Maori architecture, Hotunui, into its classical interior, but which, like some Titan in the belly of Cronus, refuses to digest it, and instead lives on as significant architecture precisely because of a binary tension generated between different architectural traditions. ${ }^{19}$

While Walker contrasted Māori biculturalism with Pākehā monoculturalism, Vasil's Biculturalism: Reconciling Aotearoa with New Zealand (1988) promoted "the notion of a bicultural New Zealand, as preferred by the Maori" over multi-culturalism. ${ }^{20}$ Vasil was an Indian-born political scientist, who had worked at Victoria University for the 21 years prior to publishing his book. His research area was stated to be "the politics of multiracial societies." 21 The book acknowledged that "the assimilationist policies which developed in the colonial heyday of the Pakeha are now clearly discredited and need urgently to be corrected," 22 and that the Treaty

\footnotetext{
${ }^{19}$ Linzey "Some Binary Architecture" n.p.

${ }^{20}$ Vasil Biculturalism p 1.

${ }^{21}$ Vasil Biculturalism backcover.

${ }^{22}$ Vasil Biculturalism backcover.
} 
confers legal rights on Māori. ${ }^{23}$ He posited the responsibility for change on Pākehā, ${ }^{24}$ and concluded that, following the Canadian Constitutional Amendment, 1987, New Zealand's Constitution "could include recognition of the essentially bi-racial, bicultural, and bilingual character of New Zealand and of the Maori as constituting the tangata whenua." 25 His definition of biculturalism is derived via its ability to "enable the two peoples to co-exist in dignity and to begin to respect and relish each other's languages, cultures and ways of life," 26 and is contrasted to "confrontation and violent conflict"27 which he suggests is inevitable if a

${ }^{23}$ Vasil Biculturalism p 21.

${ }^{24}$ Pakeha "have to initiate and facilitate a dialogue and seek change" Vasil Biculturalism p 23.

${ }^{25}$ Vasil Biculturalism p 30.

${ }^{26}$ Vasil Biculturalism $\mathrm{p} 1$.

27 "It is important for the Pakeha to recognise that, being in possession of Aotearoa and enjoying a prosperous existence in this idyllic land, they have a lot more to lose than the Maori if there is a confrontation and violent conflict between the two ethnic segments, ... It is imperative for people to understand that if the situation is allowed to drift and deteriorate and there is violent conflict, the Pakeha may find it difficult to cope successfully with violent insurgency within the country because of the widely scattered nature of human

settlement and farms, and the extremely limited means of imposing its coercive authority available to the state." bicultural approach is not undertaken.

Another Pākehā view, which accepted the need for biculturalism, is recorded in Richard Mulgan's "Can the Treaty of Waitangi provide a Constitutional Basis for New Zealand's Political Future?" Mulgan (b 1940) was a political scientist at Auckland University, and had served on the 1985-86 New Zealand Royal Commission on the Electoral System recommending MMP (Mixed Member Proportional Representation). He currently works at ANU.

Mulgan acknowledged research revealing "the difference between the English and Maori versions [of the Treaty and that] ... Maori did not accept effective sovereignty of the British Crown over their lands and people," but he states that "[a]ny practicable future for this society must be based on the premise that the predominant culture will be that of the Pakeha majority." 28 He refers to the Treaty as "the standard official phrase for the principles of biculturalism," and a positive symbol of commitment "to the principles of a just

Vasil Biculturalism p 8.

${ }^{28}$ Mulgan "Can the Treaty of Watangi provide a

Constitutional Basis for New Zealand's Political Future?" pp 53,54. bicultural future for both Pakeha and Maori."29 As part of "a tolerant, bicultural future for New Zealand ... [Mulgan anticipates] public commitment to the survival and development of Maori culture as well as of the dominant Pakeha culture ... [which] is also "indigenous" to this country ... [and] may need special protection against mass international culture."30

His notion of bicultural equality though denies Māori the power-sharing Walker advocates, Mulgan asserting that "Equal rights for Maori today means the absence of discrimination against them and their culture; it does not mean equal shares between Maori and Pakeha."31 Mulgan hence introduces an asymmetrical structure underlying a symmetrical surface for his description of the bicultural; a paternalistic model power and control, which is given to Pākehā by default, where surface appearance decorates and has

${ }^{29}$ Mulgan "Can the Treaty of Watangi provide a Constitutional Basis for New Zealand's Political Future?" pp 57,66.

${ }^{30}$ Mulgan "Can the Treaty of Watangi provide a

Constitutional Basis for New Zealand's Political Future?" p 55.

${ }^{31}$ Mulgan "Can the Treaty of Watangi provide a

Constitutional Basis for New Zealand's Political Future?" p 61. 
no structural implication.

\section{Bicultural Architecture}

The use of bicultural to describe architecture in New Zealand post-dates instances in the fine arts and literature. ${ }^{32}$ This is not to say that issues of cultural identity or discussion about building, which engaged the architectural ideas of Māori and Pākehā, had not been an ambition in some local architecture. A 1959 article on the Auckland Adult Education Centre described the building as "the only public building in Auckland to have adopted Maori features of architecture." ${ }^{33}$ The same year, an article on John Scott recorded that Scott "has not often used Maori decoration for interior panelling, but on several occasions he has found the

32 For example Ihimaera "Maori life and literature" p 54. In July 1984, Peter Shaw described artist Ian McMillan as "Making a Bicultural Statement." In the 1970s McMillan had seen talks by Bernie Kernott on "the so-called bastard-art of the 1880-1920 period," beginning a longer interest in the Te Kooti meeting houses, and making a photographic record of the East Coast houses. The later Springbok Tour, when "People were saying that Maori and Pakeha were jointly sharing the heritage of the tangata-whenua," prompted him to explore biculturalism in his work. Shaw "Making a Bicultural Statement" $p$ 121.

33 "Towards a Fuller Life for the Auckland Maori" p 47.
Maori features useful and has adapted them to the European requirements." 34 In the 1960s Gerhard Rosenberg designed houses with the aim that they "would be particularly suitable for Maori owners and tenants, and which at the same time be readily saleable to Pakehas if the need arose." 35 In the same decade the brief for the Maori Battalion Memorial (Palmerston North) required that: "the building should be a harmonious combination of Maori and Pakeha architectural traditions." 36 Futuna Chapel (formerly St Joseph's Chapel) was likewise described as benefiting from two cultural traditions. John Scott's Māori ancestry was said in 1973 to have given "him a uniqueness of approach and conceptual development," while his Catholicism meant that "both cultures [were reflected] in Futuna's Chapel to great advantage." 37

For the purposes of this conference paper though, the NZIA journals of the 1980s will serve to illustrate the emergencing discourse of bicultural architecture during the decade. While New Zealand Architect and its antecedent Architecture New Zealand have never been

\footnotetext{
${ }^{34}$ Johnson "The Work of John Scott" p 38.

${ }^{35}$ Rosenburg "Two Designs for Family Homes" pp 23-25.

36 "Maori Battalion Memorial" p 32.

37 "Futuna Chapel" p 30.
}

known for their comprehensive embracing of biculturalism, or māoritanga, the word appears in several issues of the journal and gives some insight into what bicultural architecture was considered to be within the Pākehā architectural community.

The word bicultural appears 12 times in five articles in New Zealand Architect/Architecture New Zealand in the 1980s, beginning from early 1986 (Figure 1). It is used to describe: the Waikato Museum of Art and History, Futuna Chapel, and Ringatū meeting houses. Rewi Thompson, Ivan Mercep, John Scott, and Te Kooti are positioned as engaging with New Zealand biculturalism in their architecture though with varying success - and most often within the Western framework of architect.

Russell Withers, in one of his "Life Styles?" columns, is the first author to use the term. It is in his column "Racism and Architecture" where the bicultural is introduced. The column is presented as four sections: beginning with a selection of quotations (some times contradictory), then "Devices Pakehas use to skirt around the challenge of Racism," "Background information" (providing definitions and statistics), and "References." The two uses of "bicultural" occur in the first 
and third sections, ${ }^{38}$ and promote the broader idea of biculturalism as critical to the context in which architecture is produced, rather than relating it mechanically to architecture. In both instances biculturalism is promoted as essential, and needed prior to any idea of multi-cultural New Zealand.

\begin{tabular}{|l|c|l|}
\hline Reference & $\begin{array}{c}\text { No. of } \\
\text { occurances }\end{array}$ & Date \\
\hline $\begin{array}{l}\text { Withers "Life Styles?: } \\
\text { Racism and Architecture" } \\
\text { pp 50-51 }\end{array}$ & 2 & March/April 1986 \\
\hline $\begin{array}{l}\text { Thompson "Rewi } \\
\text { Thompson ..." p 19. }\end{array}$ & 1 & Jan/Feb 1987 \\
\hline $\begin{array}{l}\text { Rae "Waikato Museum of } \\
\text { Art and History: } \\
\text { Appraisal" p. 48, 50 }\end{array}$ & 3 & May/June 1988 \\
\hline $\begin{array}{l}\text { Walden "Towards a Bi- } \\
\text { cultural Identity" p. 92. }\end{array}$ & 5 & Nov/Dec 1988 \\
\hline $\begin{array}{l}\text { Linzey "Te Kooti - } \\
\text { Architect" p. 93. }\end{array}$ & 1 & Sept/Oct 1989 \\
\hline
\end{tabular}

Fig 1. Number of occurances of bicultural/biculturalism in specific articles in New Zealand Architect/Architecture

New Zealand during the period of 1980-89.

The second article published was by Rewi Thompson. Its context was "Up From Down Under," the American lecture tour by Ian

${ }^{38}$ Withers "Life Styles?: Racism and Architecture" pp 5051.
Athfield, John Blair, Rewi Thompson and Roger Walker, which followed on the tail of the "Te Maori" exhibition. In the article Thompson discusses the personal impact of the tour (the article is paralleled with texts from the others in the same issue), and describes how it forced the group to "reassess our work before we could talk about it to the Americans, and in turn reinforced our feeling of being Kiwi." 39 He stated that "Maori people have a different approach and this will balance against some of my colleagues' ideas ... who are primarily pakeha," and he observed that Americans had "started to see how the Maori was adapting in the Pakeha world without losing their identity or integrity."40 He recalls: "I spoke about how my work reflects the bi-culturalism of Maori and Pakeha ... I think a lot of my work reflects the balance between things Maori and pakeha." ${ }^{41}$

Balance is a very different word to adapting, adopting, harmonious combination, reflecting, suitability, and usefulness - the terminology previously used to describe architectural engagements or negotiation reticient of Māori

\footnotetext{
${ }^{39}$ Thompson "Rewi Thompson ..." p 15

${ }^{40}$ Thompson "Rewi Thompson ..." p 19.

${ }^{41}$ Thompson "Rewi Thompson ..." p 19.
}

and Pākehā cultures. Phrases such as "balancing act" suggest both skill and volatility; the potential for things to go awry. Thompson distinguished Māori and Pākehā worlds using the metaphysical and the physical to describe them respectively. $\mathrm{He}$ considered his work to now show "some versatility that both Maori and European people can enjoy,"42 noting this quality as unique to New Zealand. Thompson's bicultural architecture then engaged enjoyment, process (or approach), balance, versatility and both the metaphysical and the physical.

The next three occurances of "bicultural" can be found in Barry Rae's appraisal of JASMaD's (Ivan Mercep and Chris Dale's) Waikato Museum of Art and History, Hamilton. The review is tough. He describes the "reference to whare or pataka, tacked on the back of the building ... [as] shallow and incongruous," and notes the reason for the sign "Haere Mai" is because it says things "the architecture does not tell you." ${ }^{33}$ In criticising the Tainui gallery he stated that:

\footnotetext{
${ }^{42}$ Thompson "Rewi Thompson ..." p 19

${ }^{43}$ Rae "Waikato Museum of Art and History: Appraisal" p 48 .
} 
the poupou and rafters are completely unrelated to structure, space or light. The result is a confusing pastiche of tacked on surface decoration completely unrelated to the architecture. ... No attempt has been made to explore new ways of integrating art and architecture of finding a new symbolism appropriate to contemporary buildings, new functions and a new age ... The architecture of this building does not teach me much about Maori culture. ${ }^{44}$

His use of "bicultural" is firstly to describe the museum's function, which is bicultural because "[i]t houses, amongst other things, the Taonga of the Tainui people." 45 Rae proceeds to suggest strongly that the building does not live up to this architectural function. $\mathrm{He}$ concludes that: "The challenge of a bi-cultural architecture for the next century has been ignored."46 The final reference to biculturalism in the article quotes the Governor General, Sir Paul Reeves, at the museum's opening ceremony. Reeves "commented ... that the museum could serve a vital function in encouraging people to see biculturalism as "a process of enquiry and respect, a realisation I am affected by more

${ }^{44}$ Rae "Waikato Museum of Art and History: Appraisal" p 50.

${ }^{45}$ Rae "Waikato Museum of Art and History: Appraisal" p 48.

${ }^{46}$ Rae "Waikato Museum of Art and History: Appraisal" p 48. than one cultural viewpoint."' 47 The test of this might be time, evident perhaps in Ann McEwan's more recent review of the building in 2008. ${ }^{48}$ In it there is no suggestion that the reviewer has had such a bicultural experience, the architecture seeming not to realise its obligation to affect its occupants via more than one cultural viewpoint.

It is Russell Walden who extends an architectural definition of biculturalism in his 1988 article "Towards Bi-cultural Identity," where he uses the term "bi-cultural" five times. He notes there are "few architectural reflections of ... bi-culturalism," and defines architectural biculturalism as "an architecture which carries the consensus, or the creative embrace of Maori and European values," and speaks "simultaneously to Maori and pakeha." 49 He interchanges "bi-cultural" with "indigenous," and describes this architecture as resulting in a "completely new," "timeless," synthesis. ${ }^{50}$ While Reeves proposed the idea of bicultural realisation as an awareness of

${ }^{47}$ Rae "Waikato Museum of Art and History: Appraisal" p 50.

${ }^{48}$ McEwan "Waikato Museum of Art and History, 1987" pp 76-77.

${ }^{49}$ Walden "Towards a Bi-cultural Identity" pp 92,95.

${ }^{50}$ Walden "Towards a Bi-cultural Identity" pp 92,95. different cultural perspectives, Walden's use of consensus and synthesis suggests the mutuality and unity which Walker had criticised as deriving from "the one people myth." His use of "creative" and "new" suggest innovative architecture.

Walden provides architectural examples: Glen Murcutt's Australian houses, and then John Scott's Futuna Chapel, which demonstrates its biculturalism through bringing "together Maori and pakeha values," and embracing "the tradition of barn and woolshed." 51 Farm buildings and sheds had, in the 1980s, been vested with the nostalgic mythologies of Laugier's primitive hut and the international currency of Venturi's Decorated Shed, most clearly synthesised into Mitchell and Chaplin's Elegant Shed. The theme of the woolshed and the whare, as the underpinning of John Scott's architecture (which appears to derive from Julie Dalzell's 1977 interview with Scott for Designscape), ${ }^{52}$ of course completed the equation. Yet, importantly Walden positioned Futuna as the beginning of, not the answer to, the questions of New Zealand bicultural architecture; Futuna spoke

${ }^{51}$ Walden "Towards a Bi-cultural Identity" pp 93,95.

${ }^{52}$ Dalzell "John Scott, architect" p 23. 
"poignantly about what a Pacific architecture might, could, and should be." 53 Futuna was the potential of, not the conclusion to, bicultural architecture.

Mike Linzey is the fifth and final writer to use the term "bicultural" in NZIA journals of the 1980s. His useage, "bi-cultural vision,"54 appears in a revisionist history of Te Kooti, locating him within the conventionally Western notion of architect. Like Walden, Linzey equates biculturalism with synthesis, specifically, in the case of the Ringatū wharenui, the synthesis of "symbolic aspects of Maori and European sacred traditions," 55 but he also accords the site of the bicultural, the painting of the houses, as radical, ${ }^{56}$ and bicultural architecture as one with conflicting perspectives:

The European architectural presumption that a sacred building ought to always be in perfect condition, that a church building should be preserved, repaired and maintained in its original state forever and forever, is foreign to Maori tradition. ... these houses were allowed to fall into disrepair purposefully, and out of profound respect for the tapu that was associated with them. And

\footnotetext{
${ }^{53}$ Walden "Towards a Bi-cultural Identity" p 95.

${ }^{54}$ Linzey "Te Kooti - Architect" p 93.

${ }^{55}$ Linzey "Te Kooti - Architect" p 93.

${ }^{56}$ Linzey "Te Kooti - Architect" p 93
}

the change in attitude towards restoration that we have witnessed in more recent years with respect to Rongopai in particular indicated that a point of fundamental conflict between Maori and European architectural traditions is finally finding a resolution. It is naive to judge and condemn these restorations exclusively on historical conservation criteria. ${ }^{57}$

In raising this issue, Linzey suggests that bicultural synthesis might not necessarily be seamless or comprehensive. Shortly following the publication of this article, Linzey published a second article, this time in New Zealand Historic Places. In this second article, Linzey uses "bicultural" once in his assertion that the Te Kooti wharenui are:

the best object lesson in biculturalism that New Zealand architecture has yet produced. They are of enormous value for international architecture because they are a true architecture of dialogue ... they stand out in loud defiance against mute modern buildings. ${ }^{58}$

There is perhaps a certain idealising in Linzey sentiment. The buildings are "a "true" document of history, a record unpolluted by Pakeha avarice of that time," 59 but there is also an appreciation of the complexity of the architecture of these wharenui in the way they

${ }^{57}$ Linzey "Te Kooti - Architect" p 95.

${ }^{58}$ Linzey "The tapu tradition of Ringatu houses" p 27.

${ }^{59}$ Linzey "The tapu tradition of Ringatu houses" p 27. negotiate and recognise cultural difference: "This does not [Linzey proceeds to state] deny that contradictions and polarisations between Christian/European and Maori traditions exists. But it is to assert that these differences can be contained by a single word in a living language."60

Linzey articulates a bicultural utopia - the collapsing of Reeves and Walden's positions: difference and singularity, but interestingly he also identifies the value of bicultural architecture as international. ${ }^{61}$ Like Walden (who found biculturalism manifest in the ability of buildings to: express New Zealand's "bi-cultural identity," speak both "across cultures," and "powerfully to Maori and

${ }^{60}$ Linzey "The tapu tradition of Ringatu houses" p 28. ${ }^{61}$ I have elsewhere examined the relationship of international significance and biculturalist agenda in Walden's advocacy of John Scott and Futuna, during the 1980s and beyond. (McCarthy "Voices of Silence

Reconsidered" forthcoming). Linzey's seeming rearticulation of this also coincides with the fact that both Walden and Linzey had recently returned to New Zealand from post-graduate study overseas when they began research which would engage bicultural issues. It may be that the idea of bicultural architecture both rekindled their New Zealand identities and was a vehicle for them to simultaneously reconnect back into the international world. 
pakeha consciousness"62), Linzey's articulation of bicultural architecture uses metaphors of speech, or the lack of it. The buildings are loud, they speak, and express themselves, effecting the agency and power. In Linzey's case this is no accident of the contemporary post-modernist fascination with the linguistic. An article of his the same year (1989) is titled "Speaking to and talking about Maori architecture,"63 and in it he presents an account of architecture as a "living presence ... richer than any mere simile:"64

The house is not like an ancestor, it is the ancestor ... The house is in a sense made, designed to be spoken to. ${ }^{65}$

\section{Conclusion}

By the end of the decade bicultural architecture had become the subject of student research. Thelma Rodger's 1989 BArch subthesis (supervised by Mike Linzey)

${ }^{62}$ Walden "Towards a Bi-cultural Identity" p 95. ${ }^{63}$ Linzey "Speaking to and talking about Maori architecture" pp 48-60. This article was orignally published as an essay in Dwellings, Settlements and Tradition. I am using the version of it published in Interstices in 1991.

${ }^{64}$ Linzey "Speaking to and talking about Maori architecture" p 48

${ }^{65}$ Linzey "Speaking to and talking about Maori architecture" pp 49-51. summarises the complexities of bi-culturalism:

The Pakeha myth of biculturalism perpetrated an ideal of peace and harmony and dialogue betweeen two diverse cultures that in fact concealed repression of Maori cultural values, and as the Pakeha cultural construct of dominance has diminished biculturalism has rapidly become a synonym for conflict and confusion. The two cultures are not in harmony. ${ }^{66}$

She continued describing biculturalism as both "undefined" and maleable and an artefact of the time in which biculturalism is discussed (taking "on the connotations of the current relationship of the two cultures"). ${ }^{67}$ It is, for Rodgers, "an on-going interaction of culture."68 Her location of biculturalism as time-dependent, suggests that a temporal, rather than spatial, architecture is the volatile founding of biculturalism.

It's perhaps fitting then to end with a memory - not one of mine, but rather one of Christchurch architect Peter Beaven's. It suggests the tensions of biculturalism of the 1980s, and perhaps now also, might lie in the latent desirabilities and inconveniences which define and capture the very differences of

${ }^{66}$ Rodgers "House of Biculturalism" p 4.

${ }^{67}$ my emphasis, Rodgers "House of Biculturalism" p 4.

${ }^{68}$ Rodgers "House of Biculturalism" p 4. culture Ranginui Walker articulated over 20 years ago:

One of the very many regrets in my life, which gathers in strength, was an invitation by the Arawa Maoris to build a centre for Maori activities in Rotorua. When I spoke to them, they suggested I first spend some months on the Marae in the Urewera with them, but I was caught by London and returned there instead. ${ }^{69}$ 


\section{REFERENCES}

Beaven, Peter "The Post Colonial World" New Zealand Architect (1982) 2:315.

"Bicultural" Oxford English Dictionary (Oxford: Clarendon Press, 1989) II: 173.

Brown, Deidre Māori Architecture: from fale to wharenui and beyond Auckland: Auckland University Press, 2009.

Dalzell, Julie "John Scott, architect" Designscape (June 1977):23-30.

"Dedication of Carving" Te Ao Hou: The New World (September 1968) 64:40-41.

"Futuna Chapel" Souvenir of the silver jubilee of Futuna Retreat House, 62 Friend Street, Karori, Wellington, 5, New Zealand: conducted by the Fathers and Brothers of the Society of Mary, 1948-1973 Karori [N.Z.]: Futuna Press, [1973]:28-34.

Huata, Donna Awatere "Te Mana Maori Motuhake/Maori Sovereignty" Broadsheet 106 (January/February 1983):13-14.

Ihimaera, Witi Tame "Maori life and literature: a sensory perception" Turnbull Library Record (May 1982) 15(1):54.

Innis, Hugh R. Bilingualism and biculturalism: an abridged version of the Report of the Royal Commission Report Totornot: McClelland and Stewart, c1973.

Johnson, Louis "The Work of John Scott" Te Ao Hou: The New World (September 1959) 28:36-38.

Linzey, Mike "Some Binary Architecture: sites for possible thought" Interstices (1995/1996) 4 CD ROM.

Linzey, Michael "Speaking to and talking about Maori architecture" JeanPaul Bourdier and Nezar Al Sayyad (eds). Dwelling in, Settlement and Tradition Lanham: University Press of America, 1989:317-334.

Linzey, Michael "Speaking to and talking about Maori architecture" Interstices: a journal of architecture and related arts (February 1991) 1:48-
60.

Linzey, Mike "Te Kooti - Architect" Architecture New Zealand (September/October 1989): 90-95.

Linzey, Mike "The tapu tradition of Ringatu houses" New Zealand Historic Places (June 1990) 29:26-32.

McCarthy, Christine "Voices of Silence Reconsidered" Fabrications (June 2009) 1:forthcoming

McEwan, Ann "Waikato Museum of Art and History, 1987" Architecture New Zealand (July/August 2008):76-77.

"Maori Battalion Memorial: A Distinguished Building by a Gifted Architect," Te Ao Hou 47 (June 1964):32.

"Maori Welfare Officers Meet the Minister" Te Ao Hou: The New World (November 1973) 74:13-14.

"Mental and Social Health Week" Te Ao Hou: The New World (1971) 69:13.

Mulgan, Richard "Can the Treaty of Waitangi provide a Constitutional Basis for New Zealand's Political Future?" Political Science (December 1989) 41(2):51-68.

Rae, Barry "Waikato Museum of Art and History: Appraisal" Architecture New Zealand (May/June 1988):47-50.

Report of the Royal Commission on Bilingualism and Biculturalism Otawa: Queen's Printer, 1967.

Ripoata a te Komihana mo te Kaupapa Tikanga Rua: The Report of the Bicultural Commission of the Anglican Church on the Treaty of Waitangi [Christchurch]: Provincial Secretary of the Church of the Province of New Zealand, 1986.

Rodgers, Thelma A. "House of Biculturalism: A study of the cultural constructs of Maori and Pakeha" Auckland: University of Auckland, BArch sub-thesis, 1989.

Rosenburg, G. "Two Designs for Family Homes" Te Ao Hou: The New 
World (June 1964) 47:23-25.

Shaw, Peter "Ian McMillan: making a bicultural statement" Auckland Metro: New Zealand's first city magazine (July 1984) 37:121-122.

Sinclair, D. "Tolaga Bay and its District High School: A Survey of the Tolaga Bay Community (Part 2)" Te Ao Hou: The New World (December 1959) 29:25-28,53-54.

Thompson, Rewi "Rewi Thompson ..." New Zealand Architect (1987) 1:15,18-19.

"Towards a Fuller Life for the Auckland Maori" Te Ao Hou: The New World (June 1959) 27:47.

"[untitled]" Te Ao Hou: The New World (July 1958) 23:44.

Vasil, Raj Biculturalism: Reconciling Aotearoa with New Zealand Wellington, Victoria University Press, 1988.

Walden, Russell "Towards a Bi-cultural Identity" Architecture New Zealand (November/December 1988):92-95.

Walker, Ranginui The Meaning of Biculturalism Auckland: R.J. Walker, 1986.

Withers, Russell "Life Styles? Racism and Architecture," New Zealand Architect (1986) 2:50-51. 